\title{
Standardization of Synbiotic Drinkable Fruit based Yoghurt using Lactobacillus brevis
}

\author{
Ayyavoo Preamnath Manoharan*, J. Jayapratha and C. Ashokkumar \\ Department of Food Science and Technology, College of Food and Dairy Technology, \\ Chennai-52, India \\ *Corresponding author
}

\begin{tabular}{l} 
Key w or d s \\
Yoghurt, \\
$\begin{array}{l}\text { Synbiotic, Mango, } \\
\text { Lactobacillus } \\
\text { brevis }\end{array}$ \\
\hline Article Info \\
$\begin{array}{l}\text { Accepted: } \\
\text { 15 December } 2019 \\
\text { Available Online: } \\
\text { 20January 2020 }\end{array}$ \\
\hline
\end{tabular}

\section{A B S T R A C T}

The demand for foods with specific functional characteristics and nutritional balance is increasing. This study was investigated for the feasibility of symbiotic yoghurt with Lactobacillus brevis as probiotics. This yoghurt was prepared by addition of natural fruits (mango or banana). Hereby the drinkable yoghurt might act as a good source of calcium, Vitamin D and other nutrients. The incorporation of fruits also enhances the flavour of yoghurt establishing the need to optimize the level of inclusion of these fruits in yoghurt. This study was carried out to analyze the effect of inclusion of different levels of fruits and prebiotic into yoghurt thus optimizing the composition of fortified synbiotic drinkable yoghurt. Sensory evaluation was conducted to assess the optimum inclusion levels of the above ingredients in the fortified synbiotic drinkable yoghurt. One way analysis of variance (ANOVA) was conducted to study the significance of difference among the fortified synbiotic drinkable yoghurt.

\section{Introduction}

Yoghurt is one of the health promoting delicious dairy products liked by all age groups of people throughout the world. Yoghurt production is increasing every year tremendously. According to the Code of Federal Regulations of the FDA (CFR, 2013): Yogurt is the food produced by culturing one or more of the optional dairy ingredients with a characterizing bacterial culture that contains the lactic acid-producing bacteria, Lactobacillus bulgaricus and Streptococcus thermophilus. Probiotics are defined as "living microorganisms that, upon ingestion in certain numbers, exert health benefits beyond inherent basic nutrition" (Guarner and Schaafsma, 1998). 
A similar definition was proposed by a United Nations and World Health Organization Expert Panel: "live micro-organisms which when administered in adequate amounts confer a health benefit on the host" (FAO/WHO, 2002). Younus et al., (2002) reported that the word "yoghurt" is derived from Turkish "jugurt", used to describe any fermented food with an acidic in taste.

Karagul et al., (2004) stated that yoghurt was made by fermenting milk with indigenous microorganisms. Yoghurt having high nutritional and therapeutic properties is being highly produced and consumed worldwide. Goldin et al., (1992) reported that Lactobacillus can survive and temporarily colonize the human gastrointestinal tract and can affect the metabolic activity of the resident microflora.

Samona and Robinson(1994) reported that yogurt organisms tended to suppress the growth of the bifido bacteria, subsequent storage in the presence of the yogurt cultures did not lead to any significant decline in numbers. Axelsson, (1998) stated that lactic acid bacteria (LAB) family is composed of a heterogeneous group of Gram positive, nonspore-forming, catalase- and cytochromenegative, anaerobic or aero tolerant bacteria. Ayad et al., (2004) observed that Lactobacillus brevis (B23) also showed moderate acidification activity at low $\mathrm{pH}$ with an increase in cell number found to be necessary for the production of high levels of abacteriocins like substance. Stanton, (2005) stated that the most important prebiotics are glucans, fructans and mannans. The consumption of fermented products has long been associated with good health given that they can contain probiotics, prebiotics or both.

\section{Materials and Methods}

Fresh Cow milk, Sugar, Skimmed milk powder, mango and banana pulp was purchased from the nearby super market was used to in the preparation of fortified synbiotic drinkable yoghurt. Drinkable yoghurt mix was prepared to contain a final composition of $3.5 \%$ fat, $8.5 \% \mathrm{SNF}$ and 5\% sugar in the drinkable yoghurt, as per BIS (IS: 12898, 1989) specification (Sukumar De, 2015). In each treatment, mix was preheated to $60^{\circ} \mathrm{C}$ and ingredients were homogenized as described in Arbuckle (1986) and then heated to $85^{\circ} \mathrm{C}$ for $30 \mathrm{mins}$ as suggested by Lee and Lucy (2010).

Mixes were cooled to $42^{\circ} \mathrm{C}$ and inoculated with yoghurt culture and Lactobacillus brevis at the rate of 1 per cent each and incubated for 3 to 5 hours in the incubator or till the titrable acidity reaches 0.75 per cent and cooled to 20 to $25^{\circ} \mathrm{C}$.

\section{Microbial analysis of fruit synbiotic drinkable yoghurts during storage}

Total Viable Count, Coliform, Yeast and Mold in the fortified synbiotic drinkable yoghurt were determined as per the method described by Bureau of Indian Standards described in IS:12898 - 1989.

\section{Sensory evaluation of developed product}

The sensory assessments were conducted in the Department of Food Science and Technology laboratory with sensory panelist at College of Food and Dairy Technology, Koduvalli, Chennai. A sensory score card to evaluate colour and appearance, flavor, body and texture, sweetness, sourness and overall acceptability using 9 point hedonic scale was prepared and given to the sensory panelist.

\section{Statistical analysis}

The data collected on various parameters were analyzed as per the standard method of described by Snedecor and Cochran (1989). 
Analysis of variance (one way ANOVA) was used to study the significant difference by post hoc Duncan, Tamhane's T2 procedure.

\section{Results and Discussion}

Different level of mango pulp added drinkable yoghurt Sensory scores

The average overall sensory score card for drinkable yoghurt with different levels of mango pulp is represented in Table 1.The inclusion of mango pulp at 10 per cent level had maximum sensory score of 8.11 and the samples with 5, 10 and 15 per cent inclusion had the overall average scores of 7.47,8.11 and 7.61, respectively; while the control had the average of 6.91. The inclusion of mango pulp at 10 per cent level has scored the maximum value for all the sensory characters and hence considered as optimum and chosen for further analysis.

In the present study as seen in Table 1, significant difference was observed in the sensory perception between control and mango drinkable yoghurt. The inclusion level of mango pulp into yoghurt was optimized at an acceptable level of tenper cent in the preparation of drinkable yoghurt. Studies by Venkateshaiah (1995) also showed that among pineapple, mango, banana and sapota fruit pulps tried with different levels in frozen yoghurt, mango fruit pulp at 10 per cent level was found to be highly acceptable product as compared to other types of fruit yoghurts.

Different level of banana pulp added drinkable yoghurt Sensory scores

The respective mean sensory scores for drinkable yoghurt prepared by inclusion of different levels of banana pulp. The inclusion level of banana pulp at 10 per cent level resulted in maximum score of 7.88. The samples with 5, 10 and 15 per cent inclusion had the overall average scores of 7.58, 7.88 and 7.13 respectively; while the control had the average of 6.91 shown in table 2. Since the yoghurt drink with 10 per cent banana pulp showed significant difference in sensory scores than the rest it was considered for further analysis. Tenper cent inclusion level of banana pulp for the preparation of drinkable yoghurt was found to be optimum since it scored maximum on sensory attribute as seen in table 2. In a similar study by Amna Mahmood et al., (2008), it was revealed that 8 per cent inclusion of banana pulp scored maximum followed by 10 per cent. This might be due to the amount of reducing sugar(carbohydrate) present in banana fruit.

\section{Probiotic properties of Lactobacillus brevis by bile salts tolerance test}

The bile tolerance of L.brevis to varying levels of bile salts. The respective mean viable count $\left(\log _{10} \mathrm{cfu} / \mathrm{ml}\right)$ of L.brevis for control, 0.2, 0.4 and 0.6 per cent of bile were $10.57 \pm 0.005$, $8.36 \pm 0.049, \quad 7.24 \pm 0.051$ and $6.58 \pm 0.005$ shown in table 3.Significant difference was observed in the viable counts between 0.2 per cent of bile treated culture and control. There was a decreasing trend in viability of L. brevis with increase in bile concentration. L.brevis showed tolerance to maximum bile concentration $(0.6 \%)$ with a viability of $6.58 \pm 0.005\left(\log _{10} \mathrm{cfu} / \mathrm{ml}\right)$.

From Table 3,it may be seen that the L. brevis had tolerance towards varying levels of bile salts. L. brevis showed good tolerance to 0.4 and 0.6 per cent of bile. The mean viable count $\left(\log _{10} \mathrm{cfu} / \mathrm{ml}\right)$ at 0.4 and 0.6 per cent of bile were $7.24 \pm 0.051$ and $6.58 \pm 0.005$, respectively. Thus, the prerequisite of $10^{6} \mathrm{cfu} / \mathrm{ml}$ recommended for a probiotic food as suggested by Samona and Robinson (1994) was met in this study. 
Table.1 List of various proportions of synbiotic yoghurt preparations

\begin{tabular}{|c|c|}
\hline TC & Control drinkable yoghurt (yoghurt culture + Lactobacillus brevis) \\
\hline T1 & Drinkable yoghurt + Mango (5\% pulp) \\
\hline T2 & Drinkable yoghurt + Mango (10\% pulp) \\
\hline Daa1T3 & Drinkable yoghurt + Mango (15\% pulp) \\
\hline T4 & Drinkable yoghurt + Banana (5\% pulp) \\
\hline T5 & Drinkable yoghurt + Banana (10\% pulp) \\
\hline T6 & Drinkable yoghurt + Banana (15\% pulp) \\
\hline
\end{tabular}

Table.2 Sensory scores for the drinkable yoghurt prepared with different level of mango pulp $(\mathrm{Mean} \pm \mathrm{SE})^{@}$

\begin{tabular}{|c|c|c|c|c|c|c|}
\hline \multirow{2}{*}{$\begin{array}{l}\text { Inclusion level of } \\
\text { Mango pulp in } \\
\text { yoghurt }(\%)\end{array}$} & \multicolumn{6}{|c|}{ Sensory attributes (9-point hedonic scale) } \\
\hline & $\begin{array}{l}\text { Colour and } \\
\text { Appearance }\end{array}$ & Flavor & $\begin{array}{l}\text { Body and } \\
\text { Texture }\end{array}$ & Sweetness & Sourness & $\begin{array}{c}\text { Overall } \\
\text { acceptability }\end{array}$ \\
\hline C & $6.88 \pm 0.237^{\mathrm{a}}$ & $7.18 \pm 0.102^{\mathrm{ab}}$ & $6.96 \pm 0.137^{\mathrm{a}}$ & $7.03 \pm 0.090^{\mathrm{a}}$ & $7.18 \pm 0.236^{\mathrm{a}}$ & $6.91 \pm 0.133^{\mathrm{a}}$ \\
\hline $5 \%$ & $7.60 \pm 0.165^{\text {bc }}$ & $6.95 \pm 0.194^{\mathrm{a}}$ & $7.08 \pm 0.079^{\mathrm{a}}$ & $6.91 \pm 0.169^{\mathrm{a}}$ & $6.88 \pm 0.219^{\mathrm{a}}$ & $7.47 \pm 0.126^{\mathrm{ab}}$ \\
\hline $10 \%$ & $7.87 \pm 0.144^{\mathrm{c}}$ & $8.32 \pm 0.328^{c}$ & $8.04 \pm 0.084^{b}$ & $8.378 \pm 0.187^{\mathrm{b}}$ & $7.59 \pm 0.180^{\mathrm{a}}$ & $8.11 \pm 0.232^{\mathrm{c}}$ \\
\hline $15 \%$ & $7.07 \pm 0.065^{\mathrm{ab}}$ & $7.90 \pm 0.280^{\mathrm{bc}}$ & $7.03 \pm 0.216^{\mathrm{a}}$ & $8.01 \pm 0.210^{\mathrm{b}}$ & $7.27 \pm 0.124^{\mathrm{a}}$ & $7.61 \pm 0.124^{\mathrm{bc}}$ \\
\hline
\end{tabular}

${ }^{\circledR}$ Average of eight trials

Means bearing different superscripts in a column differ significantly $(P<0.05)$

Table.3 Sensory scores for the drinkable yoghurt prepared with different level of banana pulp $($ Mean \pm SE)

\begin{tabular}{c|c|c|c|c|c|c|}
\hline $\begin{array}{c}\text { Inclusion level of } \\
\text { banana pulp in } \\
\text { yoghurt (\%) }\end{array}$ & $\begin{array}{c}\text { Colour and } \\
\text { Appearance }\end{array}$ & Flavor & $\begin{array}{c}\text { Sody and } \\
\text { Texture }\end{array}$ & Sweetness & Sourness & $\begin{array}{c}\text { Overall } \\
\text { acceptability }\end{array}$ \\
\hline Control & $6.88 \pm 0.237^{\mathrm{a}}$ & $7.18 \pm 0.102^{\mathrm{a}}$ & $6.96 \pm 0.137^{\mathrm{a}}$ & $7.03 \pm 0.090^{\mathrm{a}}$ & $7.18 \pm 0.236^{\mathrm{a}}$ & $6.91 \pm 0.133^{\mathrm{a}}$ \\
\hline $\mathbf{5 \%}$ & $7.27 \pm 0.276^{\mathrm{a}}$ & $7.30 \pm 0.248^{\mathrm{a}}$ & $7.09 \pm 0.225^{\mathrm{ab}}$ & $7.28 \pm 0.244^{\mathrm{ab}}$ & $7.12 \pm 0.243^{\mathrm{a}}$ & $7.58 \pm 0.168^{\mathrm{ab}}$ \\
\hline $\mathbf{1 0 \%}$ & $7.62 \pm 0.275^{\mathrm{a}}$ & $8.06 \pm 0.377^{\mathrm{a}}$ & $7.88 \pm 0.165^{\mathrm{b}}$ & $8.15 \pm 0.261^{\mathrm{b}}$ & $7.76 \pm 0.251^{\mathrm{a}}$ & $7.88 \pm 0.264^{\mathrm{b}}$ \\
\hline $\mathbf{1 5 \%}$ & $7.05 \pm 0.22^{\mathrm{a}}$ & $7.24 \pm 0.431^{\mathrm{a}}$ & $6.71 \pm 0.321^{\mathrm{a}}$ & $6.94 \pm 0.361^{\mathrm{a}}$ & $6.81 \pm 0.300^{\mathrm{a}}$ & $7.13 \pm 0.259^{\mathrm{ab}}$ \\
\hline
\end{tabular}

${ }^{\circledR}$ Average of eight trials

Means bearing different superscripts in a column differ significantly $(P<0.05)$

Table.4 Probiotic properties of Lactobacillus brevisby bile saltstolerance test (Mean \pm SE) ${ }^{\circledR}$

\begin{tabular}{|c|c|c|c|c|}
\hline \multirow[t]{2}{*}{ Name of the culture } & \multirow[t]{2}{*}{ Control } & \multicolumn{3}{|c|}{ Percentage of bile salt } \\
\hline & & $0.2 \%$ & $0.4 \%$ & $0.6 \%$ \\
\hline Lactobacillus brevis & $10.57 \pm 0.005^{c}$ & $8.36 \pm 0.049^{b}$ & $7.24 \pm 0.051^{\mathrm{a}}$ & $6.58 \pm 0.005^{\mathrm{a}}$ \\
\hline
\end{tabular}


Table.5 Lactobacillus brevis ${ }^{\#}$ tolerance to acidity at $\mathrm{pH}$ 3(Mean \pm SE) ${ }^{@}$

\begin{tabular}{|c|c|c|c|}
\hline \multirow{2}{*}{ Name of the culture } & \multicolumn{3}{|c|}{ Incubation period in minutes } \\
\cline { 2 - 4 } & $\mathbf{0}$ & $\mathbf{9 0}$ & $\mathbf{1 8 0}$ \\
\hline Lactobacillus brevis & $7.57 \pm 0.007^{\mathrm{c}}$ & $4.00 \pm 0.015^{\mathrm{b}}$ & $3.43 \pm 0.007^{\mathrm{a}}$ \\
\hline${ }^{\varrho}$ Average of eight trials; & ${ }^{\#} \log _{10} \mathrm{cfu}^{-1} \mathrm{ml}^{-1}$ \\
Means bearing different superscripts in a row differ significantly $(P<0.05)$
\end{tabular}

Chart.1 Preparation flow chart for Fortified synbiotic drinkable yoghurt

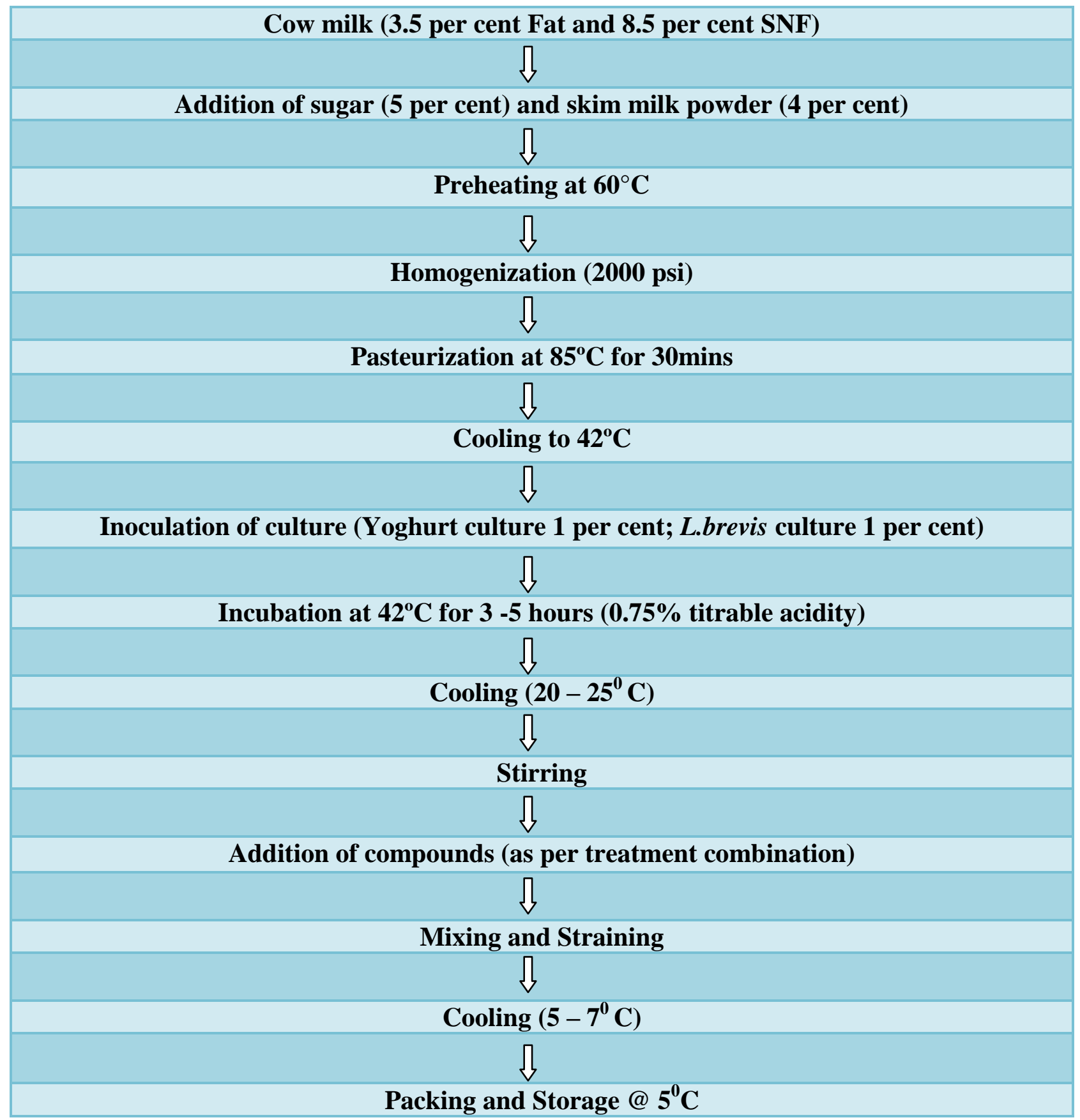


This was further affirmed by Prasad et al., (1999) who reported that one of the criteria for lactic acid bacteria to be called probiotic is its tolerance to bile salt. Jin et al., (1998) also reported that L.brevis showed tolerance to 0.3 per cent bile. In the present study the tolerance level of 0.6 per cent $\mathrm{w} / \mathrm{v}$ bile concentration was observed for L. brevis.

\section{Probiotic properties of Lactobacillus brevisto acidity at pH 3}

The tolerance of L.brevis to acidity at $\mathrm{pH} 3$. The respective mean values for tolerance of L.brevis to acidity at $\mathrm{pH} 3$ in $\left(\log _{10} \mathrm{cfu} / \mathrm{ml}\right)$ at 0,90 and 180 minutes were $7.57 \pm 0.007$, $4.00 \pm 0.015$ and 3.43 \pm 0.007 . The lowest tolerance with $3.43 \pm 0.007 \log _{10} \mathrm{cfu} / \mathrm{ml}$ was observed in 180 minutes of incubation at $\mathrm{pH} 3$ shown in Table 4. The findings are in agreement to the observations of $L$. brevis young-wood Kim et al., (2014) who stated that strains should be strongly tolerant to acidic condition as acid tolerance is an important quality for a probiotic.

The tolerance of L. brevis to acidity at $\mathrm{pH} 3$ as in most in vitro assays, $\mathrm{pH} 3$ has been preferred (Jin et al., 1994). This was in agreement with the findings of Pushkaraj Sawant et al., (2015) who reported that the fresh yoghurt contained 3.21 per cent protein and 3.35 per cent fat. As the mango pulp contains lower fat than milk, the decrease is very apparent and understandable. These results were in accordance with findings of Sengupta et al., (2014).

The addition of fruit has caused the increase in protein content of yoghurt as proved by Amna Mahmood et al., (2008). As per the Codex standards (2003) for fermented milk, there should be a minimum of 2.7 per cent of milk protein and less than 10 per cent of milk fat. The fortified synbiotic yoghurt in the present study had met the Codex requirement.
A study was conducted for the development of fortified synbiotic drinkable yoghurt. Skeletal disease of bone thinning and compromised bone strength, osteoporosis, continues to be a major public health issue as the population ages. This disease is characterized by bone fragility and an increased susceptibility to fractures, especially of the spine and hip, although any bone can be affected. Hence the drinkable yoghurt was developed by fortification with Vitamin D and calcium. This yoghurt was prepared by addition of natural fruits (mango or banana) in the presence of a prebiotic (honey or fructo-oligosaccharides). Hereby the drinkable yoghurt might act as a good source of calcium, Vitamin D and other nutrients. The incorporation of fruits also enhances the flavour of yoghurt establishing the need to optimize the level of inclusion of these fruits in yoghurt. This study was carried out to analyze the effect of inclusion of different levels of fruits and prebiotic into yoghurt thus optimizing the composition of fortified synbiotic drinkable yoghurt.

\section{References}

AmnaMahmood, N. Abbas, and A.H.Gilani, 2008. Quality of stirred buffalo milk yogurt blended with apple and banana fruits. Pak. J. Agric. Sci, 45(2):275279.

Axelsson, L., 1998. Lactic acid bacteria: classification and physiology, In Salminen S, von Wright A (ed), Lactic acid bacteria. Microbiology and functional aspects. 1 - 72

Ayad, E.H.E., S.Nashat, N.El-Sadek, H.Metwaly, and M.El-Soda, 2004. Selection of wild lactic acid bacteria isolated from traditional Egyptian dairy products according to production and technological criteria. Food microbiology, 21(6):715-725.

FAO/WHO Experts Report. 2002. Guidelines for the evaluation of probiotics in food. 
Goldin, B., S.Gorbach, M.Saxelin, S.Barakat, L.Gualtieri and S.Salminen, 1992.Survival of Lactobacillus GG in human gastrointestinal tract.Digestive Diseases and Sciences.37(1):121-128.

Guarner, F., and G.J. Schaafsma, 1998. Probiotics. International journal of food microbiology, 39(3): 237-238.

Indian Standard: 12898. 1989. Dairy productsYoghurt Specification. Bureau of Indian Standards, New Delhi.

Institute of Medicine.2012 DRI - Dietary reference intakes - Calcium and vitamin D. J Nutr Food Sci; 42:131-1.

Karagul, Y.,C.Wilson, and H.White, 2004. Formulation and processing of yoghurt. J Dairy Sci, 87:543-550.

Lee, W. J., and J.A.Lucey, 2010.Formation and Physical Properties of Yoghurt. Asian-Australian Journal of Animal Science 23(9): 1127 - 1130.

Prasad, J., H. Gill, J. Smart and P. K. Gopal, 1999.Selection and characterization of Lactobacillus and Bifidobacterium strains for use as probiotics. International Dairy Journal, 8(12):9931002.

Samona, A., and R.K.Robinson,1994. Effect of yogurt cultures on the survival of bifidobacteria in fermented milks. International Journal of Dairy Technology, 47(2): 58-60.

Sawant, P., D.Kumar, V. Patil, Yy.Ingale, Y., and Sawant, D. 2015. Physicochemical, Sensory and Microbial Quality of Yoghurt Drink Fortified with Pineapple Pulp.International Journal of Food and Fermentation Technology, 5(1), 59.

Snedecor, G.W., and W. G. Cochran, 1989. Statistical methods. $9^{\text {th }}$ Edn. The lowa State University Press, Ames, lowa.

Stanton, C., R.P.Ross,G.F. Fitzgerald, and D.V.Sinderen,2005. Fermented functionalfoods based on probiotics and their biogenic metabolites. Current Opinionin Biotechnology, 16:198-203.

Sukumar De., 2008. Outlines of dairy technology.Published by Oxford University Press, New Delhi. 183 219.

Venkateshaiah, B. V., 1995. Utilization of whey solids in the preparation of frozen yoghurt.University of Agricultural Sciences, GKVK.

Younus, S., T.Masud, and T.Aziz, 2002. Quality evaluation of market yoghurt/dahi. Pakistan Journal of Nutrition, 1(5): 226-230.

\section{How to cite this article:}

Ayyavoo Preamnath Manoharan, J. Jayapratha and Ashokkumar, C. 2020. Standardization of Synbiotic Drinkable Fruit based Yoghurt using Lactobacillus brevis. Int.J.Curr.Microbiol.App.Sci. 9(01): 527-533. doi: https://doi.org/10.20546/ijcmas.2020.901.058 